\title{
Nickel(III) containing layered double hydroxides with hydrotalcite structure
}

\author{
(C) Irina G. Ryltsova, Olga V. Nestroinaia, and Olga E. Lebedeva*+ \\ Department of General Chemistry. Institute of Pharmacy, Chemistry and Biology. \\ Belgorod State National Research University. Pobedy St., 85. Belgorod, 308015. Russia. \\ Phone: +7 (4722) 30-11-66.E-mail: OLebedeva@bsu.edu.ru
}

\begin{abstract}
*Supervising author; ${ }^{+}$Corresponding author
Keywords: layered double hydroxides, synthesis, nickel, coprecipitation, unstable oxidation state, $\mathrm{X}$-ray phase analysis, thermogravimetric analysis, transmission electron microscopy.
\end{abstract}

\section{Abstract}

Synthesis of layered double hydroxides (LDH) was carried out by the method of coprecipitating of components from the solution at room temperature and variable $\mathrm{pH}$, followed by aging at $98{ }^{\circ} \mathrm{C}$ for 2 days. During the synthesis the following compositions were specified: $\mathrm{M}^{2+}{ }_{6} \mathrm{M}^{3+}{ }_{1.5} \mathrm{Ni}^{3+}{ }_{0.5}$, where $\mathrm{M}^{2+}$ is $\mathrm{Mg}, \mathrm{Cu}$ or $\mathrm{Ca}$, $\mathrm{M}^{3+}$ is $\mathrm{Al}, \mathrm{Fe}$, or $\mathrm{Co}$. In order to convert nickel cations to oxidation state +3 , an oxidizing agent - sodium hypochlorite - was introduced into the reaction system. It is shown that the use of this method of synthesis allows to obtain layered double hydroxides containing aluminum and nickel or iron and nickel in the positions of triply charged cations in the structure of brucite-like layers. The formation of hydrotalcite-like structure was confirmed by XRD. The synthesized materials had morphology typical for layered double hydroxides. According to transmission electron microscopy, the samples consisted of aggregates of plate-like particles. The behavior during heat treatment was studied by thermogravimetric analysis. It was shown that the replacement of aluminum with iron cations in the structure of nickel-containing LDH led to a slight decrease in thermal stability of LDH. The thermal destruction of the obtained samples occured in two stages. The first stage, observed in the temperature range from 20 to $220{ }^{\circ} \mathrm{C}$, included the loss of physically sorbed and crystalline water. In the second stage, when heated above $220^{\circ} \mathrm{C}$, simultaneous dehydroxylation of brucitelike layers and removal of carbonate anions from the interlayer space were observed, which resulted in the destruction of the layered structure. Heat treatment at $500{ }^{\circ} \mathrm{C}$ led to the transformation of layered double hydroxides into a mixture of corresponding oxides.

\section{References}

[1] D.G. Evans, R.C.T. Slade. Structural aspects of layered double hydroxides. In: X. Duan, D.G. Evans (Eds.). Layered Double Hydroxides. Structure and Bonding. Springer, Berlin, Heidelberg. 2006. Vol.119. P.1-87.

[2] K.-H. Goh, T.-T. Lim, Z. Dong. Application of layered double hydroxides for removal of oxyanions: A review. Water Research. 2008. Vol.42. P.1343-1368.

[3] I.G. Ryltsova, V.A. Piskareva, O.A. Vorontsova, O.E. Lebedeva Study of kinetics of $\mathrm{Fe}^{2+}$ sorption from aqueous solution by layered double hydroxides with hydrotalcite structure. Butlerov Communications. 2016. Vol.48. No.10. P.77-82. DOI: 10.37952/ROI-jbc-01/16-48-10-77

[4] X. Bi, H. Zhang, L. Dou Layered Double Hydroxide-Based Nanocarriers for Drug Delivery. Pharmaceutics. 2014. Vol.6. P.298-332.

[5] Y.D. Tretyakov, A.V. Lukashin, A.A. Eliseev. Synthesis of functional nanocomposites based on solidphase nanoreactors. Russian Chemical Reviews. 2004. Vol.73. Iss.9. P.899-921

[6] B.F. Sels, D.E. De Vos, P.A. Jacobs. Hydrotalcite-like anionic clays in catalytic organic reactions. Catalysis Reviews. 2001. Vol.43. No.4. P.443-488.

[7] F. Li, X. Duan. Applications of Layered Double Hydroxides. In: Duan X., Evans D.G. (eds) Layered Double Hydroxides. Structure and Bonding. Springer, Berlin, Heidelberg. 2006. Vol.119. P.193-223.

[8] I.G. Ryltseva, O.A. Vorontsova, O.E. Lebedeva Catalytic properties of cobalt- and iron-containing hydrotalcite-like layered hydroxides in Knoevenagel condensation. Butlerov Communications. 2011. Vol.27. No.16. P.62-64. ROI: jbc-02/11-27-16-62

[9] D. Tichit, C. Gerardin, R. Durand, B. Coq. Layered double hydroxides: precursors for multifunctional catalysts. Topics in Catalysis. 2006. Vol.39. P.89-96. 
[10] A.B. Beleke, M. Mizuhata. Electrochemical properties of nickel-aluminum layered double hydroxide/carbon composite fabricated by liquid phase deposition. Journal of Power Sources. 2010. Vol.195. Iss.22. P.7669-7676.

[11] J. Fang, M. Li, Q. Li, W. Zhang, Q. Shou, F. Liu, X. Zhang, J. Cheng. Microwave-assisted synthesis of CoAl-layered double hydroxide/graphene oxide composite and its application in supercapacitors. Electrochimica Acta. 2012. Vol.85. P.248-245.

[12] J. Wang, Y. Song, Z. Li, Q. Liu, J. Zhou, X. Jing, M. Zhang, Z. Jiang. In Situ Ni/A1 Layered Double Hydroxide and Its Electrochemical Capacitance Performance. Energy \& Fuels. 2010. Vol.24. Iss. 12. P.6463-6467.

[13] F. Cavani, F. Trifirò, A. Vaccari. Hydrotalcite-type anionic clays: preparation, properties and applications. Catal. Today. 1991. Vol.11. P.173-301.

[14] K.B. Rozov, U. Berner, D.A. Kulik, L.W. Diamond. Solubility and thermodynamic properties of carbonate-bearing hydrotalcite-pyroaurite solid solutions with a 3:1 $\mathrm{Mg} /(\mathrm{Al}+\mathrm{Fe})$ mole ratio. Clays Clay Miner. 2011. Vol.59. P.215-232.

[15] I.G. Ryl'tsova, O.V. Nestroinaya, O.E. Lebedeva, O.A. Vorontsova, N.I. Kosova, I.A. Kurzina. New magnesium cobalt iron double hydroxides with hydrotalcite structure: synthesis and characterization. Russian Journal of Inorganic Chemistry. 2014. Vol.59. P.1403-1410.

[16] R.W. Cairns, E. Ott. X-ray studies of the system Nickel - Oxygen - Water. II. Compounds containing t rivalent Nickel. J. Am. Chem. Soc. 1933. Vol.55. P.534-544.

[17] P. Bera, M. Rajamathi, M.S. Hegde, P.V. Kamath. Thermal behaviour of hydroxides, hydroxysalts and hydrotalcites. Bulletin of Materials Science. 2000. Vol.23. P.141-145.

[18] F. Rey, V.J. Fornes. Thermal decomposition of hydrotalcites. An infrared and nuclear magnetic resonance spectroscopic study. Journal of the Chemical Society, Faraday Transactions. 1992. Vol.88. P.2233-2238. 